\title{
139. Konservative Behandlung von endoskopischen Magenperforationen
}

\author{
G. Kieninger, K. Engels, J. Durst und G. Müller \\ Chirurgische Klinik u. Medizinisches Strahleninstitut der Universität Tübingen
}

\section{Conservative Treatment of Endoscopic Perforations of the Stomach}

Summary. Gastroscopy can be complicated by the development of pneumoperitoneum due to the escape of air through a small lesion of the stomach wall. Since no gastric escapes the typical perforation symptomatology is absent. In 2800 gastroscopies this complication was seen in 5 cases. Only the first patient was operated on, and the others were treated conservatively (fasting, stomach tube); lethality was nil. The authors therefore recommend conservative therapy of pneumoperitoneum with continuous clinical observation if there are no signs of peritonitis.

Key words: Gastroscopy - Instrumental perforation of stomach - Pneumoperitoneum.

Zusammenfassung. Als Komplikation der Gastroskopie kann sich ein Pneumoperitoneum infolge Luftaustritt durch eine minimale Magenwandläsion entwickeln. Da kein Magensaft austritt, fehlt die typische Perforationssymptomatik. Bei 2800 Gastroskopien wurde diese Komplikation 5 mal beobachtet. Lediglich $1 \mathrm{mal}$ wurde laparotomiert, die folgenden Patienten wurden konservativ behandelt (Nahrungskarenz, Magensonde); keine Letalität. Die Autoren vertreten deshalb die Ansicht, daß unter kontinuierlicher stationärer Beobachtung die konservative Behandlung des Pneumoperitoneums gerechtfertigt ist, wenn die Zeichen einer Peritonitis fehlen.

Schlïsselwörter: Gastroskopie - Instrumentelle Magenperforation - Pneumoperitoneum.

\section{Vergleichende Untersuchungen verschiedener Anastomosentechniken am Verdauungstrakt des Hundes}

\author{
B. Husemann, J. Scheele, P. Klüpfel und H.-J. Pesch
}

Chirurg. Klinik mit Poliklinik (Dir.: Prof. Dr. G. Hegemann) und Patholog. Institut (Dir.: Prof. Dr. V. Becker) der Univ. Erlangen-Nürnberg

\section{Comparative Studies of Various Anastomosis Techniques in the Gastrointestinal Tract of Dog}

Summary. 104 anastomoses of the gastrointestinal tract were constructed in dogs, with 3 different suturing techniques: single-layered inverting, double-layered inverting and single-layered edge-toedge. Macroscopic, microangiographic and histologic examinations and tension testing were carried out 4,8 and 18 days after operation. The edge-to-edge anastomosis proved to be superior in all respects. Healing took place without bulges or stenosis. The resulting scar was narrow and delicate in 